\title{
PENGETAHUAN, SIKAP, DAN PRAKTEK ASI EKSLUSIF SERTA STATUS GIZI BAYI USIA 4-12 BULAN DI PEDESAAN DAN PERKOTAAN
}

\author{
(Breastfeeding Knowledge, Attitude, Practice, and 4-12 Months Infants Nutritional Status \\ In Rural and Urban Areas) \\ Asrinisa Rachmadewi ${ }^{1}$ dan Ali Khomsan ${ }^{2 *}$ \\ ${ }^{1}$ Departemen Gizi Masyarakat, Fakultas Ekologi Manusia, Institut Pertanian Bogor, Bogor 16680 \\ $2^{*}$ Alamat korespondensi: Departemen Gizi Masyarakat, Fakultas Ekologi Manusia, Institut Pertanian \\ Bogor, Bogor 16680. Tel: 0251-8621258; Fax: 0251-8622276; Email: erlangga259@yahoo.com
}

\begin{abstract}
The main aim of this study was to compare breastfeeding knowledge, attitude, and practice and infants nutritional status between rural and urban areas. In this crosssectional study, Desa Jayabakti, Kabupaten Sukabumi represents rural area, while Kelurahan Kedung Jaya, Kota Bogor represents urban area. Samples were 31 mothersinfants in each area who were selected by simple cluster sampling method. The differences between two areas were analyzed with the independent t-test, chi-square test, and Fisher's exact test. The correlation between variables was analyzed with rank Spearman. The result of this study showed that mother's knowledge and attitude of nutrition, especially about exclusive breastfeeding, was higher in urban than in rural area. There were differences in mothers' knowledge and attitude between rural and urban areas $(p<0.05)$. Exclusive breastfeeding in rural area practiced by $41.9 \%$ which is higher than in urban area $(25.8 \%$. Nevertheless, there was no statistical difference in exclusive breastfeeding practice between rural and urban areas $(p>0.05)$. The aspects of breastfeeding practices which statistically difference in rural and urban areas were the introduction of colostrums status and breastfeeding time $(p \varangle 0.05)$. Early initiation of breastfeeding was associated with exclusive breastfeeding practice in urban area $(p \varangle 0.05)$, but none of the variables were associated with exclusive breastfeeding practice in rural area $(p>0.05)$. Furthermore, exclusive breastfeeding practice was not associated with 4-12 months infants nutritional status $(p>0.05)$. Mothers' family should be targeted as target of audience in breastfeeding promotion.
\end{abstract}

Keywords: breastfeeding practice, exclusive breastfeeding, knowledge, attitude, infant nutritional status, rural and urban areas.

\section{PENDAHULUAN}

Undang-Undang no 23 tahun 2002 tentang Perlindungan Anak menyatakan bahwa pemerintah wajib memenuhi hak-hak anak, yaitu kelangsungan hidup, pertumbuhan, dan perkembangan anak. Salah satu implementasinya adalah peningkatan kerjasama dan dukungan stakeholder dalam pemberdayaan masyarakat untuk memperbaiki pola asuh balita. Perbaikan pola asuh meliputi pemberian Air Susu Ibu (ASI) secara eksklusif, penerapan inisiasi menyusu dini, serta pemberian Makanan Pendamping ASI (MP-ASI) lokal pada bayi 6 bulan ke atas dan meneruskan ASI sampai umur 2 tahun (Depkes, 2009).

Program ASI Eksklusif merupakan program promosi pemberian ASI saja pada bayi sampai dengan umur 6 bulan tanpa memberi- kan makanan atau minuman lain. Target cakupan ASI eksklusif di Indonesia pada tahun 2010 adalah $80 \%$. Survei yang dilaksanakan pada tahun 2002-2003 oleh Nutrition \& Health Surveillance System bekerjasama dengan Balitbangkes dan Helen Keller International di empat perkotaan (Jakarta, Surabaya, Semarang, Makasar) dan delapan pedesaan (Sumatera Barat, Lampung, Banten, Jawa Barat, Jawa Tengah, Jawa Timur, NTB, dan Sulawesi Selatan), menunjukkan bahwa cakupan ASI eksklusif 4-5 bulan di perkotaan sekitar $12 \%$, sedangkan di pedesaan 25\%. Pencapaian ASI eksklusif 5-6 bulan di perkotaan dan pedesaan berkisar $13 \%$.

Kendala yang dihadapi dalam praktek ASI eksklusif adalah kurangnya pengetahuan ibu dan dukungan dari lingkungan, pemberian makanan dan minuman terlalu dini, serta maraknya promosi susu formula untuk bayi (The 
American Academy of Pediatrics, 2005). Ditambahkan oleh hasil penelitian ErgenekonOzelci et al. (2006) bahwa kepercayaan tradisional, tingkat pendidikan ibu dan sikap ibu terhadap ASI yang rendah, serta perbedaan wilayah tempat tinggal menjadi kendala yang berpengaruh terhadap keberlangsungan pemberian ASI. Oleh karena itu, peneliti tertarik untuk mempelajari praktek ASI eksklusif pada bayi usia 4-12 bulan di daerah pedesaan dan perkotaan.

Tujuan umum penelitian ini adalah untuk membandingkan pengetahuan, sikap, dan praktek pemberian ASI, serta status gizi bayi usia 4-12 bulan di pedesaan dan perkotaan. Tujuan khususnya adalah (1) Mengetahui karakteristik ibu dan bayi, (2) Mempelajari pengetahuan dan sikap gizi ibu, (3) Mempelajari praktek pemberian ASI, (4) Mengkaji praktek pemberian susu non-ASI dan MP-ASI, (5) Menganalisis faktor yang berhubungan dengan pengetahuan dan sikap gizi ibu, (6) Menganalisis faktor yang berhubungan dengan pemberian ASI eksklusif, serta (7) Menganalisis hubungan pemberian ASI eksklusif dengan status gizi bayi.

\section{METODE PENELITIAN}

\section{Desain, Tempat dan Waktu}

Desain penelitian ini adalah cross sectional study. Penelitian dilakukan di dua tempat yang mewakili daerah pedesaan dan perkotaan. Daerah perkotaan diwakili oleh Kelurahan Kedung Jaya, Kecamatan Tanah Sareal, Kota Bogor, sedangkan daerah pedesaan diwakili oleh Desa Jayabakti, Kecamatan Cidahu, Kabupaten Sukabumi. Pengambilan data berlangsung mulai April - Mei 2009.

\section{J umlah dan Cara Penarikan Contoh}

Contoh penelitian adalah pasangan ibu dengan bayi usia 4-12 bulan yang memberikan ASI pada bayinya di kedua daerah penelitian. Contoh terdiri dari 31 pasang ibu-bayi masingmasing di daerah pedesaan dan perkotaan dengan metode pengambilan contoh gugus sederhana (simple cluster sampling). Desa dan kelurahan digugus berdasarkan Posyandu yang ada, kemudian secara acak dipilih Posyandu untuk diteliti seluruh pasangan ibu-bayi yang memenuhi kriteria hingga mencapai minimal 30 pasang ibu-bayi (Singarimbun \& Effendi, 1989). Posyandu yang terpilih adalah Posyandu Tunas Muda II dan Tunas Muda VIII untuk mewakili Desa Jayabakti, sedangkan Kelurahan Kedung
Jaya diwakili oleh Posyandu Wijaya Kusuma dan Melati.

\section{J enis dan Cara Pengumpulan Data}

Jenis data yang dikumpulkan terdiri dari data primer dan data sekunder. Data pimer meliputi karakteristik ibu, karakteristik bayi, pengetahuan, dan sikap gizi ibu, praktek ASI eksklusif, serta praktek pemberian susu nonASI dan MP-ASI. Data sekunder mencakup gambaran umum daerah penelitian serta daftar pasangan ibu-bayi yang memenuhi kriteria.

\section{Pengolahan dan Analisis Data}

Data yang diperoleh diolah dan dianalisis secara statistik deskriptif dan inferensia. Data yang dikumpulkan melalui wawancara dan pencatatan dikomputerisasi dengan menggunakan perangkat lunak Microsoft Excell 2007.

Data karakteristik ibu terdiri dari usia, tingkat pendidikan, status kerja, dan pengalaman menyusui sebelumnya. Usia ibu diklasifikasi menjadi tiga kelompok $(<19,19-29$, dan $\geq 30$ tahun). Tingkat pendidikan dibagi menjadi lima golongan yaitu tidak sekolah atau tidak tamat SD, tamat SD atau sederajat, tamat SMP atau sederajat, tamat SMA atau sederajat, dan tamat akademi atau perguruan tinggi. Status kerja ibu dibedakan atas ibu bekerja dan ibu tidak bekerja (ibu rumah tangga). Pengalaman menyusui sebelumnya diperoleh dari ada atau tidaknya anak yang disusui sebelumnya.

Data karakteristik bayi terdiri atas berat lahir, status inisiasi menyusu dini, dan status gizi. Berat lahir bayi dibagi menjadi dua kategori, yaitu BBLR $(<2500 \mathrm{~g})$ dan normal $(>2500$ g). Status inisiasi menyusu dini dibedakan berdasarkan bayi yang melakukan inisiasi menyusu dini dan bayi yang tidak melakukannya. Status gizi bayi dikelompokkan berdasarkan z-score dari pengukuran $P B$ dan $U$ mengacu pada indeks $\mathrm{PB} / \mathrm{U}$ referensi WHO/NCHS yang diperoleh dengan menggu-nakan rumus:

$$
\text { Z-score }=\frac{\text { PB aktual }- \text { PB median kelompok acuan }}{\text { standar deviasi kelompok acuan }}
$$

Pengetahuan dan sikap ibu tentang gizi diukur dengan menggunakan pertanyaan yang kemudian diberi nilai. Pengetahuan gizi, khususnya ASI eksklusif terdiri atas 10 pertanyaan pilihan berganda (best answer multiple choice test). Setiap jawaban yang benar diberi nilai 2 , jawaban yang salah diberi nilai 1 , dan jawaban tidak tahu diberi nilai 0 sehingga nilai maksimum dan minimum yang dapat diperoleh adalah 20 dan 0 dan kemudian dikonversi men- 
jadi 100 dan 0. Selain itu, terdapat dua pertanyaan terbuka yang menggambarkan persepsi ibu tentang keuntungan ASI bagi anak dan hal negatif dari susu non-ASI.

Sikap gizi diukur dari 10 pertanyaan dengan pilihan jawaban setuju, ragu-ragu, dan tidak setuju. Jawaban yang benar diberi nilai 2, jawaban yang salah diberi nilai 0 , sedangkan jawaban ragu-ragu diberi nilai 1 . Selanjutnya, pengetahuan dan sikap ibu masing-masing dikelompokkan menjadi tiga kategori, yaitu kurang (persentase jawaban benar $<60 \%$ ), sedang (persentase jawaban benar $60-80 \%$ ), dan baik (persentase jawaban benar $>80 \%$ ) (Khomsan, 2000).

Praktek pemberian ASI secara umum terdiri atas praktek ASI eksklusif dan alasannya, durasi pemberian ASI saja, pemberian kolostrum, waktu pemberian ASI, frekuensi pemberian ASI sehari, dan status menyusui saat ini. Selain itu, terdapat data praktek pemberian susu non-ASI dan pemberian MP-ASI. Seluruh data tersebut diolah secara deskriptif kemudian hasilnya dibandingkan antara daerah pedesaan dengan daerah perkotaan dan dianalisis untuk mengetahui hubungan antar variabel.

Uji beda dilakukan dengan menggunakan independent t-test, chi-square test, dan Fisher's exact test. Hubungan antar variabel dianalisis dengan menggunakan uji korelasi Spearman. Seluruh uji dilakukan pada taraf nyata $(\alpha) 5 \%$.

\section{HASIL DAN PEMBAHASAN}

\section{Karakteristik Ibu dan Bayi}

Ibu di pedesaan mayoritas berada pada usia 19-30 tahun dan $\geq 30$ tahun dengan persentase masing-masing sebesar $48.4 \%$. Ibu di perkotaan mayoritas berusia 19-30 tahun (61.3\%). Tingkat pendidikan ibu di pedesaan mayoritas (32.3\%) tamat SD/sederajat, sedangkan di perkotaan mayoritas (45.2\%) tamat akademi/perguruan tinggi. Ibu di pedesaan maupun perkotaan mayoritas tidak bekerja $\mathbf{( 9 3 . 5 \%}$ dan 77.4\%). Sebanyak 64.5\% Ibu di pedesaan telah mempunyai pengalaman menyusui sebelumnya, sedangkan di perkotaan hanya $48.4 \%$ ibu yang telah memiliki pengalaman menyusui sebelumnya.

Bayi di pedesaan mayoritas (38.7\%) berada pada usia 4-6 bulan, sedangkan di perkotaan mayoritas (41.9\%) berada pada usia 10-12 bulan. Di pedesaan, mayoritas merupakan bayi perempuan, sedangkan di perkotaan mayoritas merupakan bayi laki-laki. Berat lahir bayi di pedesaan $93.5 \%$ normal, sedangkan di perkotaan seluruh bayi lahir dengan berat normal. Bayi di pedesaan maupun perkotaan mayoritas (64.5\% dan 51.6\%) tidak mengalami proses inisiasi menyusu dini. Status gizi bayi baik di pedesaan maupun perkotaan mayoritas normal (64.5\% dan $83.9 \%)$.

\section{Pengetahuan dan Sikap Gizi lbu}

Pengetahuan gizi ibu di perkotaan secara umum lebih tinggi dibandingkan pedesaan. $\mathrm{Hal}$ ini terlihat dari persentase pengetahuan gizi ibu dengan kategori tinggi di perkotaan mencapai $77.4 \%$, sedangkan di pedesaan hanya $29 \%$. Rata-rata nilai pengetahuan gizi ibu di pedesaan adalah $73.4 \pm 2.4$, sedangkan di perkotaan rata-ratanya sebesar $88.4 \pm 2.2$. Nilai terbesar yang diperoleh di pedesaan maupun perkotaan adalah 100, sedangkan nilai terkecil di pedesaan sebesar 45 dan di perkotaan 55 . Hasil uji beda menunjukkan bahwa terdapat perbedaan yang nyata antara pengetahuan gizi ibu di pedesaan dan perkotaan $(p=0.000)$.

Sikap adalah penilaian dari seseorang terhadap suatu objek (Schiffman \& Kanuk 1997). Sikap gizi ibu di pedesaan secara umum lebih rendah dibandingkan perkotaan. Hal ini terlihat dari persentase ibu yang memiliki sikap dengan kategori sedang mendominasi di pedesaan $(58.1 \%)$, sedangkan di perkotaan sebagian besar ibu memiliki sikap dengan kategori tinggi (77.4\%). Rata-rata nilai sikap ibu di pedesaan adalah $73.1 \pm 2.5$, sedangkan ratarata nilai di perkotaan lebih tinggi, yaitu 83.1 \pm 2 .2. Nilai terbesar yang diperoleh di pedesaan adalah 90 dan nilai terkecilnya adalah 40 , sedangkan di perkotaan nilai terbesar adalah 100 dan nilai terkecilnya adalah 50. Hasil uji beda menunjukkan bahwa terdapat perbedaan yang nyata antara sikap gizi ibu di pedesaan dan perkotaan $(p=0.004)$.

Paparan informasi tentang ASI eksklusif lebih banyak diperoleh ibu di perkotaan. Hal ini dapat terlihat dari persentase media yang digunakan untuk mengetahui informasi ASI eksklusif yang lebih beragam. Ibu di perkotaan memperoleh informasi selain dari petugas kesehatan, keluarga dan kader Posyandu juga dari teman atau tetangga, media cetak, TV, internet, dan buku. Di pedesaan sumber informasi terpusat pada petugas kesehatan (40.4\%), keluarga (24.3\%), dan kader posyandu (16.2\%). Media lain yang digunakan oleh ibu di pedesaan untuk memperoleh informasi tentang ASI eksklusif antara lain paraji (dukun bayi terlatih) dan buku. 


\section{Praktek Pemberian ASI}

ASI eksklusif didefinisikan sebagai pemberian ASI kepada bayi sampai dengan 6 bulan secara langsung oleh ibunya dan tidak diberikan makanan cair atau padat lainnya kecuali obat tetes atau sirup yang berisi suplemen vitamin, mineral, atau obat (Gibney et al., 2005). Praktek ASI eksklusif lebih banyak ditemukan di pedesaan dibandingkan perkotaan. Hal ini terlihat dari persentase praktek ASI eksklusif (Tabel 1) di pedesaan yang lebih tinggi (41.9\%) dibandingkan perkotaan (25.8\%). Meskipun demikian, hasil uji beda dengan menggunakan chi-square test tidak menunjukkan perbedaan yang nyata antara praktek ASI eksklusif di pedesaan dan perkotaan $(p=0.108)$. Anjuran dari bidan merupakan alasan yang mendominasi (30.8\%) ibu untuk melakukan ASI eksklusif di pedesaan. Di perkotaan, alasan yang mendominasi ibu untuk melakukan praktek ASI esklu-sif adalah ibu mengetahui bahwa ASI meru-pakan makanan terbaik untuk bayi (45.5\%). Durasi pemberian ASI saja baik di pedesaan maupun perkotaan mayoritas masih $\leq 2$ bulan dan tidak terdapat perbedaan yang nyata antara kedua daerah ( $p>0.05)$.

Memberikan cairan tambahan pada bayi yang terlalu dini berbahaya bagi kesehatan bayi karena dapat meningkatkan risiko kekurangan gizi dan serangan penyakit (Academy for Educational Development, 2002). Lebih lanjut ditambahkan oleh Siregar (2004) bahwa pemberian cairan atau makanan tambahan pada bayi sebelum waktunya dapat menyebabkan ibu sulit menyusui dan cenderung berhenti menyusui.

Seluruh ibu di pedesaan telah memberikan kolostrum kepada bayinya pasca melahirkan. Hal ini berbeda nyata dengan yang ditemukan di perkotaan $(\mathrm{p}<0.05)$. Terdapat $19.4 \%$ ibu yang tidak memberikan kolostrum pada bayinya di perkotaan. Hal ini tidak sejalan dengan pengetahuan gizi ibu di perkotaan yang lebih dari $90 \%$ menyatakan kolostrum sebagai makanan terbaik untuk bayi yang baru lahir serta sikap gizi ibu yang menyetujui bahwa kolostrum baik untuk kesehatan bayi (93.5\%). Tidak diberikannya kolostrum di perkotaan diduga disebabkan oleh kurangnya dorongan dari penolong kelahiran dan keluarga akan pentingnya pemberian kolostrum dan ASI sedini mungkin pada bayi yang baru lahir. Hapsari (2006) dalam penelitiannya menyatakan penolong persalinan, usia kehamilan, dan wilayah tempat tinggal berpengaruh terhadap pemberian kolostrum.

Salah satu dari sepuluh langkah menuju keberhasilan pemberian ASI yang direkomendasikan WHO adalah dengan mendorong pemberian ASI menurut permintaan bayi (WHO, 1998). Seluruh ibu di pedesaan memberikan ASI setiap bayi meminta, sedangkan di perkotaan hanya $71 \%$ ibu yang memberikan ASI setiap bayi meminta. Hasil uji beda menggunakan Fisher's exact test menunjukkan perbedaan nyata antara waktu pemberian ASI di pedesaan dan perkotaan $(\mathrm{p}<0.05)$.

Tabel 1. Sebaran Praktek Pemberian ASI pada Bayi Usia 4-12 Bulan di Pedesaan dan Perkotaan

\begin{tabular}{|c|c|c|c|c|c|}
\hline \multirow{2}{*}{ Praktek ASI Eksklusif } & \multicolumn{2}{|c|}{ Pedesaan } & \multicolumn{2}{|c|}{ Perkotaan } & \multirow{2}{*}{ Uji Beda } \\
\hline & $n$ & $\%$ & $\mathbf{n}$ & $\%$ & \\
\hline \multicolumn{6}{|l|}{ Praktek pemberian ASI } \\
\hline Eksklusif & 13 & 41.9 & 8 & 25.8 & \multirow{2}{*}{$p=0.108$} \\
\hline Non-Eksklusif & 18 & 58.1 & 23 & 74.2 & \\
\hline \multicolumn{6}{|l|}{ Durasi Pemberian ASI (bulan) } \\
\hline$\leq 2$ & 17 & 54.8 & 20 & 64.5 & \multirow{3}{*}{$p=0.402$} \\
\hline $2-4$ & 1 & 3.2 & 3 & 9.7 & \\
\hline $4-6$ & 13 & 41.9 & 8 & 25.8 & \\
\hline \multicolumn{6}{|l|}{ Status Pemberian Kolostrum } \\
\hline Ya & 31 & 100.0 & 25 & 80.6 & \multirow{2}{*}{$\mathrm{p}=0.024^{*}$} \\
\hline Tidak & 0 & 0.0 & 6 & 19.4 & \\
\hline \multicolumn{6}{|l|}{ Waktu Pemberian ASI } \\
\hline Setiap bayi meminta & 31 & 100.0 & 22 & 71.0 & \multirow{2}{*}{$\mathrm{p}=0.002^{*}$} \\
\hline Lainnya & 0 & 0.0 & 9 & 29.0 & \\
\hline \multicolumn{6}{|l|}{ Frekuensi Pemberian ASI Sehari } \\
\hline$\geq 7$ kali & 30 & 96.8 & 29 & 93.5 & \multirow{2}{*}{$p=1.000$} \\
\hline$<7$ kali & 1 & 3.2 & 2 & 6.5 & \\
\hline \multicolumn{6}{|l|}{ Status Menyusui Saat Ini } \\
\hline $\mathrm{Ya}$ & 30 & 96.8 & 28 & 90.3 & \multirow{2}{*}{$p=0.612$} \\
\hline Tidak & 1 & 3.2 & 3 & 9.7 & \\
\hline
\end{tabular}

*berbeda nyata pada $\alpha=5 \%$ 
Perkins dan Vannais (2004) menyatakan bahwa ketika bayi berusia 3-6 bulan frekuensi pemberian ASI sekitar 7-8 kali/hari. Hampir seluruh ibu baik di pedesaan maupun perkotaan memberikan ASI lebih dari 7 kali sehari. Hanya terdapat $3.2 \%$ ibu di pedesaan yang memberikan ASI kurang dari 7 kali sehari, sedangkan di perkotaan terdapat $6.5 \%$ ibu yang memberikan ASI kurang dari 7 kali sehari. Hasil uji beda dengan menggunakan Fisher's exact test menunjukkan tidak terdapat perbedaan yang nyata antara frekuensi pemberian ASI di daerah pedesaan dengan perkotaan $(p>0.05)$.

ASI eksklusif merupakan pemberian ASI saja sampai bayi berusia 4-6 bulan. Setelah itu, bayi harus tetap mendapatkan ASI paling tidak sampai berusia 2 tahun yang disertai dengan makanan pendamping ASI. Mayoritas ibu yang menjadi responden pada penelitian ini masih memberikan ASI. Terdapat $3.2 \%$ ibu di pedesaan dan $9.7 \%$ ibu di perkotaan yang ketika penelitian sudah tidak memberikan ASI pada bayinya. Tidak terdapat perbedaan nyata antara status menyusui saat ini antara pedesaan dan perkotaan $(p>0.05)$.

\section{Praktek Pemberian Susu Non-ASI dan MP-ASI}

Pemberian susu non-ASI seperti susu formula menjadi salah satu penyebab ibu tidak memberikan ASI eksklusif kepada bayinya (Gibney et al., 2005). Sebagian besar ibu di pedesaan $(67.7 \%)$ mengaku belum pernah mengenalkan susu formula kepada bayinya ketika penelitian dilakukan. Berbeda halnya dengan di perkotaan, hanya $29 \%$ bayi yang belum pernah diperkenalkan susu non-ASI. Sebagian besar bayi $(35.5 \%)$ di perkotaan telah dikenalkan susu non-ASI sejak lahir. Hal ini disebabkan karena bayi di perkotaan sebanyak $41.9 \%$ memperoleh susu formula dari petugas kesehatan. Ibu yang memberikan atau tidak memberikan susu non-ASI sebagian mendapat bujukan dari pihak lain untuk memberikan susu non-ASI kepada bayi. Persentase keberadaan bujukan lebih tinggi di perkotaan daripada pedesaan. Baik ibu di perkotaan maupun pedesaan mendapat bujukan terbanyak dari pihak keluarga, petugas kesehatan dan teman atau tetangga.

Di pedesaan, dari $32.3 \%$ ibu yang memberikan susu non-ASI seluruhnya memberikan susu formula dengan rata-rata konsumsi 3 kali/ hari atau $1786 \mathrm{~g}$ dalam sebulan. Biaya yang dihabiskan untuk membeli susu formula rata-rata sebesar Rp. 125000 per bulan. Alokasi biaya yang lebih besar dikeluarkan oleh ibu di perkotaan. Sekitar Rp. 215000 per bulan dikeluar- kan oleh ibu untuk membeli rata-rata $1.838 \mathrm{~g}$ susu setiap bulannya.

Setelah bayi berusia 6 bulan, ASI tidak lagi dapat mencukupi kebutuhan gizi yang optimal untuk perkembangan bayi. Oleh karenanya dibutuhkan MP-ASI yang diperkenalkan secara perlahan agar tidak menimbulkan reaksi buruk terhadap makanan tersebut (Gibney et al., 2005). Ketika penelitian dilakukan, terdapat $22.6 \%$ bayi di perde-saan dan $9.7 \%$ bayi di perkotaan yang belum memperoleh MP-ASI. Hal ini dikarenakan bayi masih berusia kurang dari 6 bulan. Ibu di pedesaan lebih sedikit yang memberikan MP-ASI secara tepat baik jenis dan frekuensinya sesuai usia bayi dibandingkan ibu di perkotaan. Mayoritas frekuensi pemberian MP-ASI adalah 3-4 kali/hari. Jenis MP-ASI yang paling banyak dikonsumsi adalah bubur susu instan dan buah.

\section{Faktor yang Berhubungan dengan Pengetahu- an dan Sikap Gizi lbu}

Pengetahuan gizi ibu di pedesaan secara nyata berhubungan positif dengan usia ibu $(r=0.4902, p=0.0051)$, status kerja $(r=0.3595$, $p=0.0470$ ), dan pengalaman menyusui sebelumnya $(r=0.3691, p=0.0410)$. Sikap gizi ibu berhubungan nyata positif dengan status kerja $(r=0.3661, p=0.0428)$ dan pengetahuan gizi $(r=0.4428, p=0.0126)$. Pengetahuan gizi dengan sikap gizi ibu memiliki hubungan nyata yang positif baik di pedesaan maupun perkotaan. Hal ini sejalan dengan komponen kognitif dari sikap menurut Schiffman dan Kanuk (1997) yang menyatakan bahwa sikap adalah gambaran pengetahuan dan persepsi terhadap suatu objek sikap.

Tingkat pendidikan ibu nyata berhubungan positif dengan pengetahuan $(r=0.4489$, $p=0.0113)$ dan sikap gizi ibu $(r=0.4382$, $p=0.0137)$ di perkotaan. Hal ini sesuai dengan penelitian Adwinanti (2004) yang menyatakan terdapat hubungan yang nyata antara tingkat pendidikan ibu dengan pengetahuan dan sikap gizi ibu. Tingkat pendidikan ibu di perkotaan tergolong tinggi dengan mayoritas ibu merupakan tamatan SMA dan perguruan tinggi atau akademi sehingga informasi tentang gizi dan ASI eksklusif dapat diperoleh lebih banyak.

\section{Faktor yang Berhubungan dengan Praktek ASI Eksklusif}

Terdapat beberapa faktor yang diduga berhubungan dengan praktek ASI eksklusif. Foo et al., (2005) menyatakan faktor yang berhubungan dengan praktek ASI eksklusif diantaranya karakteristik ibu dan bayi, pengetahuan, 
dan informasi dari tenaga kesehatan. Faktor yang diduga berhubungan dengan praktek ASI eksklusif dan dianalisis dalam penelitian ini adalah karakteristik ibu (usia, tingkat pendidikan, status kerja, dan pengalaman menyusui sebelumnya), karakteristik bayi (berat lahir dan status inisiasi menyusu dini), serta pengetahuan dan sikap gizi ibu. Tidak ditemukan faktor yang berhubungan dengan praktek ASI eksklusif pada bayi usia 4-12 bulan di pedesaan $(p>0.05)$. Hal ini diduga disebabkan adanya faktor lain yang berhubungan dengan praktek ASI eksklusif, seperti budaya dan kepercayaan tradisional yang tidak diteliti pada penelitian ini.

Faktor yang diduga berhubungan dengan praktek ASI eksklusif di perkotaan antara lain usia ibu, tingkat pendidikan, status kerja, pengalaman menyusui sebelumnya, status inisiasi menyusu dini, serta pengetahuan dan sikap gizi ibu. Berat lahir bayi tidak dianalisis seperti di pedesaan, karena seluruh bayi di perkotaan lahir dengan berat normal. Faktor yang berhubungan nyata positif dengan praktek ASI eksklusif di perkotaan adalah status inisiasi menyusu dini ( $r=0.4616, p=0.0090)$. Bayi yang mengalami inisiasi menyusu dini cenderung mendapatkan ASI eksklusif. Hal ini sesuai dengan penelitian mahasiswa Trisakti (2003) yang diacu dalam sebuah artikel Asosiasi Ibu Menyusui Indonesia (2008) bahwa bayi yang mengalami inisiasi menyusu dini berpeluang 8 kali lebih besar untuk berhasil ASI eksklusif. WHO (1998) juga menyatakan bahwa inisiasi menyusui dini menjadi salah satu dari 10 kunci keberhasilan menyusui.

\section{Hubungan Praktek ASI Eksklusif dengan Sta- tus Gizi Bayi}

Status gizi bayi diklasifikasikan berdasarkan z-score yang dihitung menggunakan indeks $\mathrm{PB} / \mathrm{U}$. Hasil uji korelasi Spearman menunjukkan tidak terdapat hubungan yang nyata antara praktek ASI eksklusif dengan status gizi bayi $(p>0.05)$ (Tabel 2). Hal ini tidak sesuai dengan penelitian Adwinanti (2004) yang menyatakan bahwa terdapat hubungan yang nyata antara praktek pemberian ASI dengan status gizi bayi. Sementara itu, hasil penelitian lainnya menun- jukkan kesesuaian dengan hasil penelitian ini, bahwa tidak terdapat hubungan yang nyata antara praktek pemberian ASI dengan status gizi bayi (Suciarni, 2004; Rahayu, 2005).

Boyle (2003) menyatakan, pertumbuhan bayi sangat tergantung dari diet atau asupan makanan. Bayi yang diberi makan selain ASI sebelum waktunya berisiko tinggi terkena infeksi. Hal ini dapat menjadi dugaan bahwa pemberian makanan selain ASI serta kejadian infeksi atau status kesehatan bayi dapat berhubungan dengan status gizi bayi. Persentase bayi dengan status gizi pendek dan tinggi yang cukup besar diduga disebabkan oleh kurang tepatnya pemberian MP-ASI. Seperti yang telah dijelaskan sebelumnya, masih terdapat bayi yang belum memperoleh MP-ASI sesuai dengan usianya baik dalam hal frekuensi maupun jenisnya.

\section{KESIMPULAN}

Ibu di pedesaan dan perkotaan mayoritas berusia antara 19-30 tahun. Tingkat pendidikan ibu di pedesaan mayoritas tamat SD/ sederajat, sedangkan di perkotaan mayoritas tamat akademi/perguruan tinggi. Mayoritas ibu di pedesaan telah mempunyai pengalaman menyusui sebelumnya, sedangkan di perkotaan mayoritas tidak memiliki pengalaman menyusui sebelumnya. Berat lahir bayi di pedesaan 93.5\% normal, sedangkan di perkotaan seluruh bayi lahir dengan berat normal. Bayi di pedesaan maupun perkotaan mayoritas tidak mengalami proses inisiasi menyusu dini. Status gizi bayi di pedesaan dan perkotaan mayoritas normal.

Pengetahuan dan sikap gizi ibu di pedesaan mayoritas sedang, sedangkan di perkotaan mayoritas tinggi. Terdapat perbedaan yang nyata antara tingkat pengetahuan dan sikap gizi ibu di pedesaan dengan perkotaan.

Persentase praktek ASI eksklusif di pedesaan lebih besar dibandingkan perkotaan, namun tidak berbeda nyata. Mayoritas ibu di pedesaan dan perkotaan memberikan ASI saja $\leq 2$

Tabel 2. Hubungan Praktek Pemberian ASI Eksklusif dengan Status Gizi Bayi

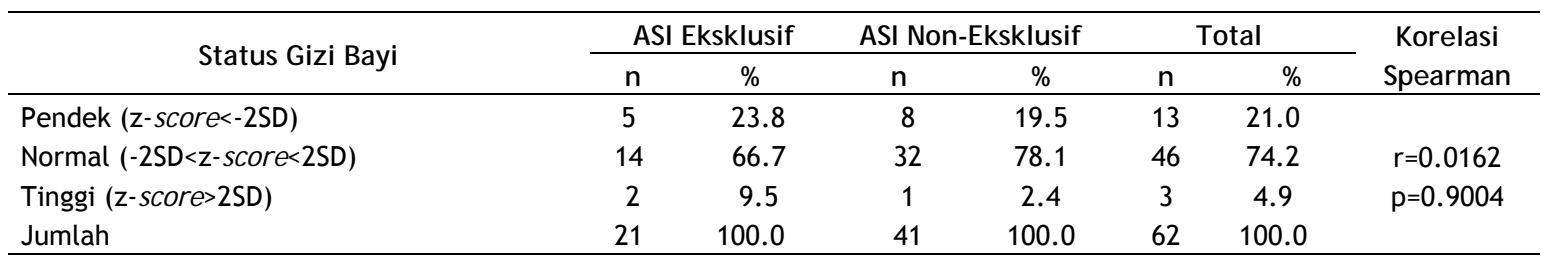


bulan, dan tidak terdapat perbedaan yang nyata di kedua daerah. Seluruh ibu di pedesaan memberikan kolostrum kepada bayinya, sedangkan di perkotaan hanya 90.3\% Di pedesaan, seluruh ibu memberikan ASI setiap bayi meminta, sedangkan di perkotaan waktu pemberian ASI lebih bervariasi. Hampir seluruh ibu di pedesaan dan perkotaan memberikan ASI $\geq 7$ kali/hari dan berstatus masih menyusui sampai saat penelitian dilakukan. Tidak terdapat perbedaan yang nyata antara frekuensi pemberian ASI dan status menyusui saat ini di pedesaan dengan perkotaan.

Mayoritas bayi di pedesaan belum pernah mengonsumsi susu non-ASI ketika penelitian berlangsung. Mayoritas bayi di perkotaan telah mengonsumsi susu formula sejak lahir. Praktek pemberian MP-ASI di daerah pedesaan dan perkotaan baik frekuensi maupun jenis yang diberikan masih kurang sesuai dengan usia bayi.

Pengetahuan gizi ibu berhubungan nyata positif dengan sikap gizi ibu di pedesaan maupun perkotaan. Faktor yang berhubungan nyata dengan pengetahuan gizi ibu di pedesaan adalah usia ibu, status kerja, dan pengalaman menyusui sebelumnya. Faktor yang berhubungan nyata dengan sikap gizi ibu di pedesaan adalah status kerja. Di perkotaan, hanya tingkat pendidikan ibu yang berhubungan nyata dengan tingkat pengetahuan serta sikap gizi ibu.

Tidak terdapat faktor yang berhubungan nyata dengan praktek ASI eksklusif di pedesaan, sedangkan di perkotaan status inisiasi menyusu dini menjadi satu-satunya faktor yang berhubungan nyata dengan praktek ASI eksklusif. Tidak terdapat hubungan yang nyata antara praktek ASI eksklusif dengan status gizi bayi.

\section{DAFTAR PUSTAKA}

[Depkes RI]. 2009. Rencana Kerja Program Perbaikan Gizi (Penanggulangan Gizi Kurang dan Buruk) Tahun 2009. Direktorat Gizi Masyarakat, Depkes RI, Jakarta

Academy for Educational Development. 2002. Exclusive breastfeeding: the only water source young infants need-frequently asked questions. Linkages ed. October 2002.

Adwinanti V. 2004. Hubungan Praktek Pemberian ASI dengan Pengetahuan Ibu tentang
ASI, Kekhawatiran Ibu, Dukungan Keluarga dan Status Gizi Bayi Usia 0-6 Bulan. Skripsi Sarjana Departemen Gizi Masyarakat, Fakultas Pertanian, IPB, Bogor.

Asosiasi Ibu Menyusui Indonesia. 2008. Menyusui pada Satu Jam Pertama. http: / / aimiasi.org/2008/04/hello-world/[9 Februari 2009].

Boyle MA. 2003. Community Nutrition in Action $3^{\text {rd }}$ ed. Wadsworth, Thomson Learning Inc., USA.

Ergenekon-Ozelci P, N Elmaci, M Ertem, G Saka. 2006. Breastfeeding beliefs and practices among migrant mothers in slums of Diyarbakir, Turkey, 2001. European Journal of Public Health 16(2),143148.

Foo LL, SJS Queck, MT Lim, M Deurenberg-Yap. 2005. Breastfeeding prevalence and practices among Singaporean chinese, malay, and indian mothers. Health Promotion International 20 (3).

Gibney MJ, MM Barrie, MK John, A Leonore. 2005. Public Health Nutrition. Blackwell Publishing Ltd., Oxford.

Hapsari D. 2006. Telaah berbagai faktor yang berhubungan dengan pemberian kolostrum. http://ekologi.litbang.depkes.go. id/data/abstrak/DwiHapsari. [10 Juni 2009].

Khomsan A. 2000. Pengukuran Tingkat Pengetahuan Gizi. Fakultas Pertanian, IPB, Bogor.

Perkins S, C Vannais. 2004. Breastfeeding for Dummies. USA: Wiley Publishing, Inc.

Pranadji DK. 1988. Pendidikan Gizi (Proses Belajar Mengajar). Fakultas Pertanian, IPB, Bogor.

Rahayu PR. 2005. Pengetahuan, Sikap, dan Perilaku Ibu dalam Pemberian ASI dan MP. ASI pada Anak Baduta di Pedesaan dan Perkotaan. Skripsi Sarjana Departemen Gizi Masyarakat, Fakultas Pertanian, IPB, Bogor.

Schiffman LG, Kanuk. 1997. Consumer Behavior $6^{\text {th }}$ Ed. New Jersey: Prentice Hall, Inc. 
Singarimbun M, S Effendi. 1989. Metode Penelitian Survai. LP3ES, Jakarta.

Siregar A. 2004. Faktor-Faktor yang Mempengaruhi Pemberian ASI oleh Ibu Melahirkan. USU Digital Library, Medan

Suciarni E. 2004. Hubungan Pengetahuan dan Sikap Ibu terhadap ASI Eksklusif Sampa Usia 6 Bulan. Skripsi Sarjana Departemen
Gizi Masyarakat, Fakultas Pertanian, IPB, Bogor.

The American Academy of Pediatrics. 2005. Policy statement: Breastfeeding and the use of human milk. Pediatrics 115(2), 496-506.

WHO. 1998. Evidence to The Ten Steps for Successful Breastfeeding. WHO, Geneva. 